Article

\title{
Novel Synthesis of 8-Deaza-5,6,7,8-tetrahydroaminopterin Analogues via an Aziridine Intermediate
}

\author{
Shouxin Zhou ${ }^{1}$, Chao Tian ${ }^{1}$, Chao Li ${ }^{1}$, Ying Guo ${ }^{1}$, Xiaowei Wang ${ }^{1}$, Junyi Liu ${ }^{1,2}$ and \\ Zhili Zhang ${ }^{1, *}$
}

1 Department of Chemical Biology, School of Pharmaceutical Sciences, Peking University, Beijing 100191, China

2 State Key Laboratory of Natural and Biomimetic Drugs, Peking University, Beijing 100191, China

* Author to whom correspondence should be addressed; E-Mail: lilybmu@bjmu.edu.cn; Tel.: +86-10-8280-5203; Fax: +86-10-8280-1706.

Received: 10 April 2012; in revised form: 3 May 2012 / Accepted: 5 May 2012 /

Published: 10 May 2012

\begin{abstract}
An efficient method for the construction of the tetrahydrofolate skeleton is described. Starting from pterin analogues and aromatic amines, 8-deaza-5,6,7,8tetrahydroaminopterin derivatives and the heterocyclic benzoyl isosteres were synthesized via a novel aziridine intermediate. Following this method, the byproducts of carbonnitrogen bond hydrogenolysis in traditional synthetic strategy can be completely avoided.
\end{abstract}

Keywords: tetrahydrofolate; aziridine; catalytic hydrogenation; solvent-free

\section{Introduction}

Tetrahydrofolate plays a central role in one-carbon metabolism involving DNA biosynthesis, and the biologically active cofactor forms are substrates for at least 15 relevant enzymes [1-4]. Hence, tetrahydrofolate analogues are widely used as inhibitors of folate-dependent enzymes for chemotherapy. Early in 1960s, tetrahydrohomofolate (Figure 1) was found to be a potent inhibitor against TS (thymidine synthase) [5]. After then, more tetrahydrofolate analogues were developed as antitumor drugs, including lometrexol [6] as a specific inhibitor of GARFT (glycinamide ribonucleotide formyl transferase), AG2034 [7] and LY309887 [8] as next-generation GARFT inhibitors, side chain modified 5-deazatetrahydrofolate analogues [9] as potential dual inhibitors of 
FPGS (folylpolyglutamate synthetase) and GARFT as therapeutic agents, compound $\mathbf{1}$ and its analogues as MS (methionine synthase) and DHFR (dihydrofolate reductase) inhibitors [10].

Figure 1. Tetrahydrofolate and tetrahydroaminopterin analogues.<smiles>Nc1nc(O)c2c(n1)NCC(CCNc1ccc(C(=O)N[C@@H](CCC(=O)O)C(=O)O)cc1)C2</smiles><smiles>Nc1nc(O)c2c(n1)NCC(CCc1ccc(C(=O)N[C@@H](CCC(=O)O)C(=O)O)cc1)C2</smiles><smiles>Nc1nc(O)c2c(n1)NCC(CCc1ccc(C(=O)N[C@@H](CCC(=O)O)C(=O)O)s1)S2</smiles><smiles>Nc1nc(O)c2c(n1)NCC(CCc1ccc(C(=O)N[C@@H](CCC(=O)O)C(=O)O)s1)C2</smiles>

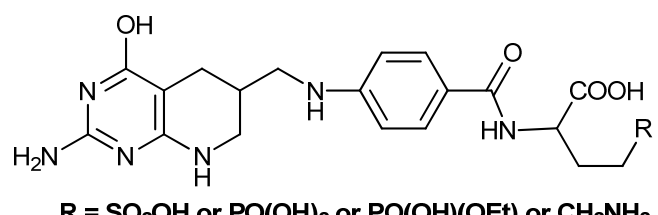<smiles>Nc1nc(N)c2c(n1)CCC(CNc1ccc(C(=O)N[C@@H](CCC(=O)O)C(=O)O)cc1Br)N2CCBr</smiles>

$\mathrm{R}=\mathrm{SO}_{2} \mathrm{OH}$ or $\mathrm{PO}(\mathrm{OH})_{2}$ or $\mathrm{PO}(\mathrm{OH})(\mathrm{OEt})$ or $\mathrm{CH}_{2} \mathrm{NH}_{2}$ Side chain modified 5-deazatetrahydrofolate analogues

ZL033

In our research on new antifolate inhibitors, we have identified $N$-[4-\{(2-[2,4-diamino-5-(2,3dibromopropane)-5,6,7,8-tetrahydropyrido(3,2-d) pyrimidin-6-yl]methyl)amino 3-3-bromobenzoyl]-Lglutamic acid (ZL033) [10,11], which inhibits methionine synthase $\left(\mathrm{IC}_{50}: 1.4 \pm 0.4 \mu \mathrm{mol} / \mathrm{L}\right)$ and proliferation of HL-60 cells $\left(\mathrm{IC}_{50}: 2.0 \pm 1.0 \mu \mathrm{mol} / \mathrm{L}\right.$ ). Despite the remarkable biological importance of tetrahydrofolate analogues, not many synthetic approaches have been reported. The common synthesis strategy [12-15] is based on a critical step which is catalytic hydrogenation of folate derivatives, and was the strategy we used in synthesis of ZL033 and a series of novel 8-deazatetrahydrofolate derivatives as DHFR and MS inhibitors (Scheme 1). The reductive hydrogenation is a critical step in the entire synthetic scheme due to the benzylic hydrogenolysis of the $\mathrm{C}^{9}-\mathrm{N}^{10}$ bond as a side reaction. Careful adjustment of reaction solution acidity and protection of $\mathrm{N}^{10}$ with an electron-withdrawing substituent before reduction didn't work well either. Against this background, we now report a practical and novel method for synthesizing 8-deazatetrahydrofolate $\mathbf{1}$ by ring-opening of an aziridine intermediate. Following this method, ZL033 and its heterocyclic benzoyl isosteres can be synthesized. And the modification in the side chain of 8-deazatetrahydrofolate can lead to more optional tetrahydrofolate analogues.

Scheme 1. Reported route for compound 1.

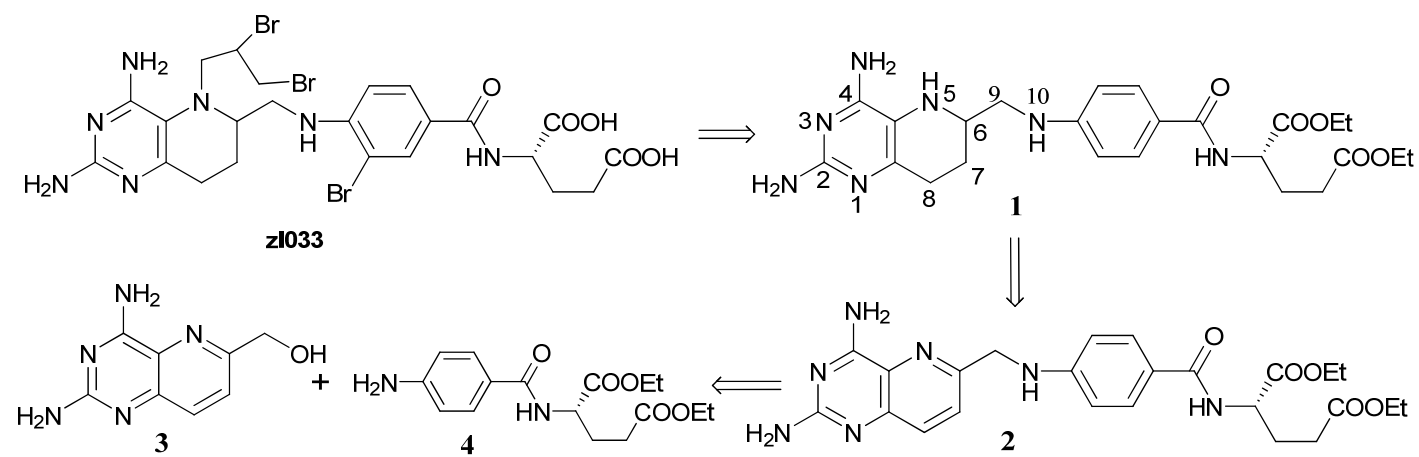




\section{Results and Discussion}

\subsection{Retrosynthetic Analysis of $\mathbf{1}$}

Our synthetic strategy is displayed in Scheme 2. Compound $\mathbf{1}$ is a key intermediate which can be converted into ZLO33 easily by the same method in Scheme 1, so we focused on the convenient synthesis of $\mathbf{1}$. We envisaged that target compound $\mathbf{1}$ and its derivatives could be constructed by ring-opening of aziridine 5 with aromatic amines. The aziridine 5 would be synthesized via cyclization of compound $\mathbf{6}$, which could be obtained by catalytic hydrogenation of compound $\mathbf{3}$. Accordingly, we started our synthetic studies by seeking a general and practical method for preparing the reduced compound 6.

Scheme 2. Synthetic strategy.

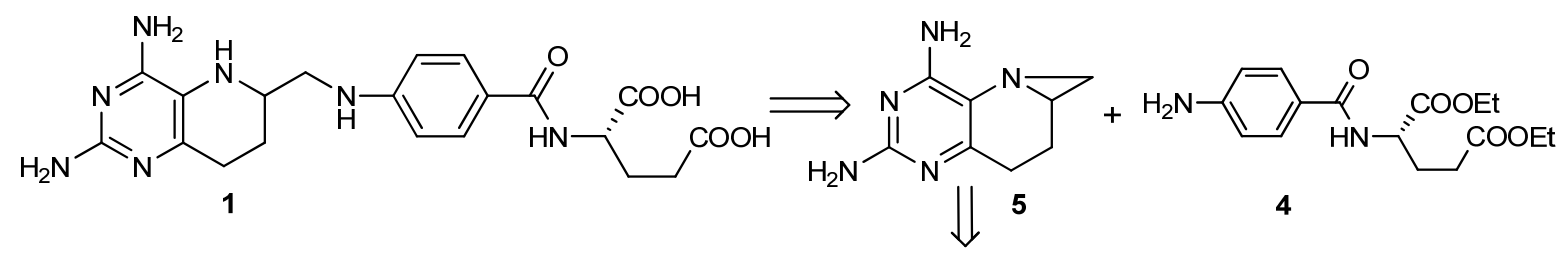<smiles>Nc1nc(N)c2nc(CO)ccc2n1</smiles><smiles>C=C=C</smiles>

\subsection{Catalytic Hydrogenation of $\mathbf{3}$}

Compound 3 was prepared in the same way as before [16,17], and was catalytically hydrogenated directly before linking with the side-chain amine to avoid $\mathrm{C}^{9}-\mathrm{N}^{10}$ hydrogenolysis (Scheme 3 ). As there is no fragile $\mathrm{C}^{9}-\mathrm{N}^{10}$ bond in $\mathbf{3}$, stronger acidic conditions could be used compared to the similar hydrogenation in Scheme 1. An initial screening of the influence of different acidic conditions (Table 1) revealed that moderate acidity gave better results. The reduction reaction didn't happen without acid added (Table 1, entry 1). Weak acids such as acetic acid gave product in 50 60\% yield, even when excess acid was used as solvent (Table 1, entries 2 4), while the yield increased obviously with hydrochloric acid (Table 1, entries 5 7). Treatment of 3 with 8 equivalents of $\mathrm{HCl}$ for $24 \mathrm{~h}$ gave compound 6 in $93 \%$ yield, but with 16 equivalents of $\mathrm{HCl}$, the yield was only $78 \%$. The reason is that the hyroxymethyl group at 6-position of compound 3 could be reduced to 6-methyl group over $\mathrm{PtO}_{2}$ under strong acidic conditions. We actually got the 6-methyl isoster of compound 6 in $12 \%$ yield under the conditions of entry 7 .

Scheme 3. Catalytic hydrogenation of 3.<smiles>Nc1nc(N)c2nc(CO)ccc2n1</smiles>

3<smiles>O=C(O)O[PH](=O)(=O)O</smiles>

solvent<smiles>Nc1nc(N)c2c(n1)CCC(CO)N2</smiles> 
Variation of solvent also affected the yield strongly (Table 1, entries 6 and 8 9). Ethanol was a better solvent under these reaction conditions than methanol and acetone. The best conditions we found featured eight equivalents of hydrochloric acid in ethanol (Table 1, entry 6), resulting in a higher yield (93\%) and the workup is easier than with the reduction reaction in Scheme 1.

Table 1. Optimization of the catalytic reduction conditions ${ }^{\text {a }}$.

\begin{tabular}{cccccc}
\hline Entry & Acid & Equiv. & Solvent & Time (h) & Yield (\%) $^{\mathbf{b}}$ \\
\hline 1 & - & - & Ethanol & 120 & - \\
2 & $\mathrm{AcOH}$ & 4 & Ethanol & 60 & 54 \\
3 & $\mathrm{AcOH}$ & 8 & Ethanol & 60 & 47 \\
4 & $\mathrm{AcOH}$ & excess & AcOH & 60 & 59 \\
5 & $\mathrm{HCl}^{\mathrm{c}}$ & 4 & Ethanol & 24 & 82 \\
6 & $\mathrm{HCl}^{\mathrm{c}}$ & 8 & Ethanol & 24 & 93 \\
7 & $\mathrm{HCl}^{\mathrm{c}}$ & 16 & Ethanol & 24 & 78 \\
8 & $\mathrm{HCl}^{\mathrm{c}}$ & 8 & Methanol & 8 & 21 \\
9 & $\mathrm{HCl}^{\mathrm{c}}$ & 8 & Acetone & 48 & 46 \\
\hline
\end{tabular}

a Conditions: Compound $3(1 \mathrm{mmol}), \mathrm{H}_{2}(0.3 \mathrm{MPa}), \mathrm{PtO}_{2}(0.1 \mathrm{mmol})$, acid $(4 \sim 16 \mathrm{mmol}$ or as solvent), solvent $(15 \mathrm{~mL}), \mathrm{H}_{2} \mathrm{O}\left(0 \sim 8 \mathrm{~mL}\right.$, from $\mathrm{HCl}$ solution). ${ }^{\mathrm{b}}$ Yield of isolated product. ${ }^{\mathrm{c}} 2 \mathrm{~mol} / \mathrm{L}$ aqueous $\mathrm{HCl}$ solution was used.

\subsection{Optimized Synthesis of $\mathbf{5}$}

Before trying this synthetic strategy, we attempted to directly synthesize $\mathbf{1}$ from $\mathbf{6}$ in several ways, but none of them succeeded. The hypothetical Mitsunobu reaction between 6 and diethyl $N$-( $p$-aminobenzoyl)-L-glutamate 4 wouldn't proceed, and methods of transferring the hydroxymethyl group in $\mathbf{6}$ to aldehyde or halidemethyl group couldn't improve this condensation reaction.

Inspired by the work of Singh [18], which described silica gel induced condensation of aziridines and aromatic amines, we designed aziridine 5 as the key intermediate [19-21]. Compound 6 was converted to the 6-chloromethyl derivative 7 in refluxing $\mathrm{POCl}_{3}$ (yield $40 \%$ ), which was then treated with $\mathrm{KOH}, \mathrm{K}_{2} \mathrm{CO}_{3}$ or 1,8-diazabicycloundec-7-ene (DBU) to give 5 in $86 \%$ yield after chromatographic purification, as shown in Scheme 4.

Scheme 4. Two-step synthesis of compound 5.<smiles>CC(C)C(C)(C)CO</smiles><smiles>Nc1nc(N)c2c(n1)CCC(CCl)N2</smiles><smiles>Nc1nc(N)c2c(n1)CCC1CC21</smiles>

Compounds 7 and 5 were both identified by ${ }^{1} \mathrm{H}-\mathrm{NMR},{ }^{13} \mathrm{C}-\mathrm{NMR}$ and ESI-MS. The ${ }^{1} \mathrm{H}-\mathrm{NMR}$ (DMSO- $d_{6}$ ) spectrum of 7 revealed a multiplet signal at $\delta 4.06 \sim 3.92 \mathrm{ppm}$ assignable to $\mathrm{CH}_{2} \mathrm{Cl}$, which obviously differed from the $\mathrm{CH}_{2} \mathrm{OH}$ group signal $\left(\delta 4.97 \sim 4.90 \mathrm{ppm}\right.$ ) of compound 6 . The ${ }^{13} \mathrm{C}-\mathrm{NMR}$ (DMSO- $d_{6}$ ) spectrum of 7 also displayed a different signal at $\delta 47.35 \mathrm{ppm}$ assignable to $\mathrm{CH}_{2} \mathrm{Cl}$ with the $\mathrm{CH}_{2} \mathrm{OH}$ group signal at $\delta 51.79 \mathrm{ppm}$ for 6. The ESI-MS result of 7 gave the intuitive proof of a 
chloride atom by a pair of isotopic peaks (214.1 and 216.1, 3:1). The ${ }^{1} \mathrm{H}-\mathrm{NMR}$ (DMSO- $d_{6}$ ) spectrum of 5 displayed two doublet signals at $\delta 2.14 \mathrm{ppm}(\mathrm{d}, J=5.2 \mathrm{~Hz}, 1 \mathrm{H})$ and $1.56 \mathrm{ppm}(\mathrm{d}, J=4.0 \mathrm{~Hz}, 1 \mathrm{H})$ which were readily assigned to the two hydrogen atoms attached at methylene position of the aziridine ring and the ${ }^{13} \mathrm{C}$-NMR (DMSO- $d_{6}$ ) spectrum of 5 displayed a new signal at $\delta 33.33$ ppm assignable to $\mathrm{NCH}_{2}$ in aziridine ring and a signal at $\delta 35.23 \mathrm{ppm}$ assignable to $\mathrm{NCH}$ which gave both a relatively high-field shift compared to compounds 7 or 6 . High resolution MS provided further confirmation for the two products.

The reaction above was somewhat low-yielding and its work-up procedure was complicated. After further investigation, we found an alternative method to obtain 5 in one step by treatment of $\mathbf{6}$ with $p$-toluenesulfonyl chloride, aqueous $\mathrm{NaOH}$ and tetrabutylammonium iodide in a two-phase system (Scheme 5). The yield increased to about 50\%, and the work-up was simplified.

Scheme 5. One-step synthesis of compound $\mathbf{5}$.<smiles>Nc1nc(N)c2c(n1)CCC(CO)N2</smiles><smiles>CC(C)(C)ONOC(C)(C)C(C)(C)C</smiles><smiles>Nc1nc(N)c2c(n1)CCC1CN21</smiles>

\subsection{Synthesis of $\mathbf{1}$}

Compounds 5, 4 and actived silica gel were mixed and shaken thoroughly under solvent-free conditions (Scheme 6). The desired product 1 was obtained in $90 \%$ yield, and the small amount of impurities could be removed easily by column chromatography. Compared with usual ring-opening reactions of aziridines using Lewis acid catalysis [22-25], the silica gel-induced method was convenient, green and cheap. Product 1 was verified by ${ }^{1} \mathrm{H}-\mathrm{NMR}$ and ESI-MS, and it was compared with the same compound prepared by Scheme 1 to prove the structural consistency.

Scheme 6. Synthesis of 1 under solvent-free conditions.

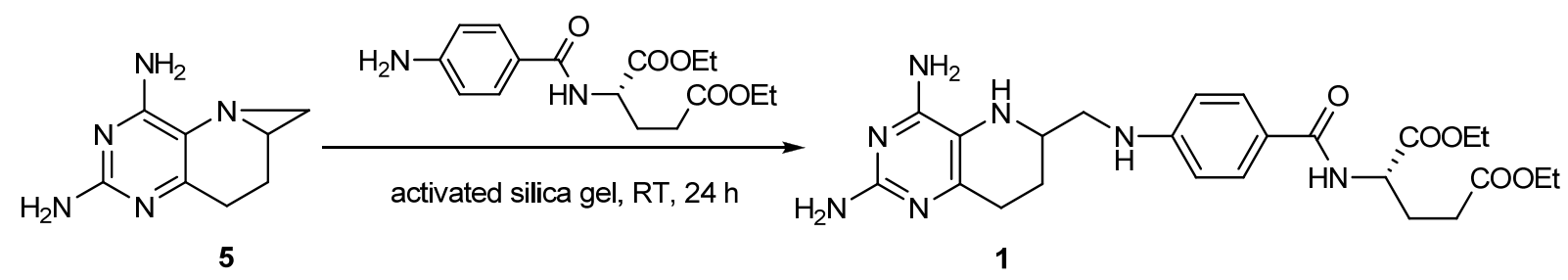

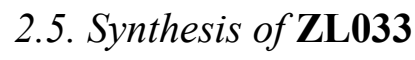

Compound 1 can be converted to ZL033 in the same reaction sequence of allyl substitution, bromination and hydrolysis as before [11] (Scheme 7). 
Scheme 7. Synthesis of ZL033 from 1.<smiles>CCOC(=O)CC[C@H](NC(=O)c1ccc(NCC2CCc3nc(N)nc(N)c3N2)cc1)C(=O)OCC</smiles>

1<smiles>Nc1nc(N)c2c(n1)CCC(CNc1ccc(C(=O)N[C@@H](CCC(=O)O)C(=O)O)cc1Br)N2CC(Br)CBr</smiles>

ZL033<smiles>C=CCN1c2c(N)nc(N)nc2CCC1CNc1ccc(C(=O)N[C@@H](CCOC(=O)OCC)C(=O)OCC)cc1</smiles>

8 $\mathrm{Br}_{2}, \mathrm{THF}, 7 \mathrm{~h}$<smiles>CCOC(=O)CCC[C@@H](NC(=O)c1ccc(NCC2CCc3nc(N)nc(N)c3N2CC(Br)CBr)c(Br)c1)C(=O)OCC</smiles>
9

\subsection{Synthesis of Other Tetrahydrofolate Analogues}

Aside from ZL033, many other tetrahydrofolate analogues can be synthesized from intermediate 1 by simply modifying the substituents on $\mathrm{N}^{5}$ or $\mathrm{N}^{10}$. Furthermore, the strategy above can be used for synthesis of various compounds, such as heterocyclic benzoyl analogues and modification in the side chain of tetrahydrofolate. Earlier research proved that substitution of $\mathrm{N}^{10}$-phenyl by aromatic heterocycles benefited inhibitory activity against several kinases [26-29]. The synthetic route of heterocyclic benzoyl analogues was similar with that of ZL033, including the ring-opening of aziridine by aromatic heterocyclic amines (Scheme 8). Compounds 10, 11 and 12 were obtained in acceptable yields by the solid-phase reaction catalysed by silica gel.

Scheme 8. Synthesis of heterocyclic benzoyl analogues of $\mathbf{1}$.

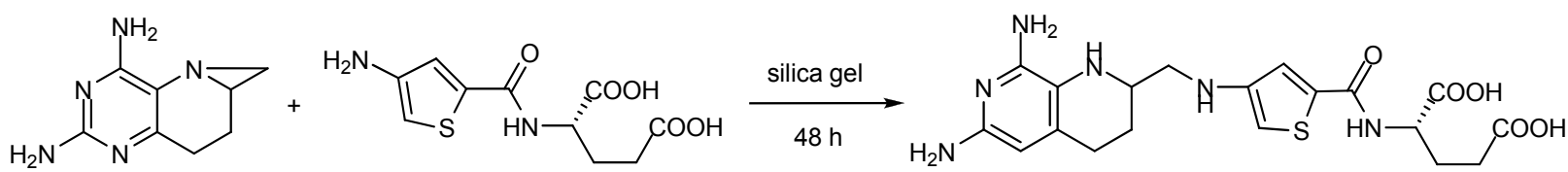

5

10<smiles>Nc1cc2c(c(N)n1)NC(CNc1ccc(C(=O)N[C@@H](CCC(=O)O)C(=O)O)s1)CC2</smiles>

11<smiles>Nc1nc(N)c2c(n1)CC[CH+]C2</smiles>

5<smiles>COC(=O)c1ccc(N)o1</smiles>

$36 \mathrm{~h}$<smiles>COC(=O)c1ccc(NCC2CCc3cc(N)nc(N)c3N2)o1</smiles>

12

Compounds 10, 11 and 12 were transformed into analogues of ZL033 by substitution and hydrolysis reactions. This novel synthetic route is flexible to a certain extent. With various pteridines and aniline analogues, more tetrahydroaminopterin and tetrahydrofolate analogues were prepared in this novel method. The studies of these heterocyclic analogues of 8-deazatetrahydrofolate on the antifolate activity and the structure-activity relationship will be published in the future. 


\section{Experimental}

\subsection{General}

All reactions were monitored by TLC analysis (pre-coated silica gel plates with fluorescent indicator UV254, $0.2 \mathrm{~mm}$ ) and visualized with $254 \mathrm{~nm}$ UV light. The products were purified by column chromatography on silica gel (silica gel 230-400 mesh or silica gel H, produced by Qingdao Ocean-Chem Inc., Qingdao, China), or preparative thin layer chromatography on silica gel (silica gel $\mathrm{GF}_{254}, 0.5 \mathrm{~mm}$, also produced by Qingdao Ocean-Chem Inc., Qingdao, China). ${ }^{1} \mathrm{H}-\mathrm{NMR}$ spectra were measured on Bruker avance III 400 spectrometer (400 MHz, Bruker Co., Fällanden, Switzerland) or JEOL JNM-AL300 spectrometer (300 MHz, Joel, Japan). Data were reported as follows: Chemical shifts in ppm from tetramethylsilane as an internal standard in $\mathrm{CDCl}_{3}$ or DMSO- $d_{6}$, multiplicity ( $\mathrm{s}=$ singlet, $\mathrm{d}=$ doublet, $\mathrm{t}=$ triplet, $\mathrm{q}=$ quartet, $\mathrm{m}=$ multiplet, $\mathrm{br}=$ broad $)$, coupling constants $(\mathrm{Hz})$, integration. ${ }^{13} \mathrm{C}$-NMR spectra were recorded on a Bruker Avance III 400 (100 MHz) or JEOL JNM-AL300 spectrometer $(75 \mathrm{MHz})$. Mass spectra were measured with a Quattro micro 2000 (ESI-TOF) instrument (Bruker Co., Bremen, Germany). HRMS was performed on a Bruker APEX IV FT-MS (7.0T, Waters, New Castle, DE, USA). Melting points were measured with a SGW X4 microscopic melting point apparatus. Chemicals were purchased from Aldrich, Acros, AlfaAsar, Strem, OuheChem or Beijing Chemical Works and were used without further purification, unless otherwise noted. Hydrogen gas needed in reduction reaction was supplied by a GCD-300A hydrogen generator, manufactured by the Beijing BCHP Analytical Technology Institute.

(2,4-Diamino-5,6,7,8-tetrahydropyrido[3,2-d]pyrimidin-6-yl)methanol (6): To a suspension of 2,4-diamino-6-hydroxymethylpyrido[3,2-d]pyrimidine $(3,2.01 \mathrm{~g}, 10.5 \mathrm{mmol})$ in ethanol $(150 \mathrm{~mL})$ was added aqueous $\mathrm{HCl}(40 \mathrm{~mL}, 2 \mathrm{~mol} / \mathrm{L}, 80 \mathrm{mmol})$ and platinum dioxide monohydrate $(250 \mathrm{mg}$, $1.0 \mathrm{mmol}$ ). The mixture was then hydrogenated in a $0.3 \mathrm{MPa}$ hydrogen generator at room temperature for $24 \mathrm{~h}$. After evaporation of solvents and acid, anhydrous ethanol $(300 \mathrm{~mL})$ was added to the residue and stirred for $1 \mathrm{~h}$. The resulting precipitate was filtered, washed with acetone $(100 \mathrm{~mL})$ and dried under vacuum to afford $1.90 \mathrm{~g}\left(92.9 \%\right.$ yield) of 6 as a white solid; m.p. 241 243 ${ }^{\circ} \mathrm{C}$. ${ }^{1} \mathrm{H}-\mathrm{NMR}$ (300 MHz, DMSO- $d_{6}$ ): $\delta=7.90$ (br.s, $2 \mathrm{H}, 4-\mathrm{NH}_{2}$ ), 6.93 (br.s, 2H, 2-NH ), 4.97 4.90 (br.s $\times 2,2 \mathrm{H}$, $\left.\mathrm{CH}_{2} \mathrm{OH}\right), 3.47 \sim 3.41(\mathrm{~m}, 1 \mathrm{H}, 6-\mathrm{CH}), 3.16\left(\mathrm{~m}, 1 \mathrm{H}, 8-\mathrm{CH}_{\mathrm{a}} \mathrm{H}_{\mathrm{b}}\right), 2.68 \sim 2.59\left(\mathrm{~m}, 1 \mathrm{H}, 8-\mathrm{CH}_{\mathrm{a}} H_{\mathrm{b}}\right), 1.93 \sim 1.88$ $\left(\mathrm{m}, 1 \mathrm{H}, 7-\mathrm{CH}_{\mathrm{a}} \mathrm{H}_{\mathrm{b}}\right), 1.53\left(\mathrm{~m}, 1 \mathrm{H}, 7-\mathrm{CH}_{\mathrm{a}} H_{\mathrm{b}}\right) ;{ }^{13} \mathrm{C}-\mathrm{NMR}\left(75 \mathrm{MHz}, \mathrm{DMSO}-d_{6}\right): \delta=157.47(\mathrm{C}-8 \mathrm{a}), 150.52$ (C-4), 129.18 (C-2), 116.39 (C-4a), $63.92\left(\mathrm{CH}_{2} \mathrm{OH}\right), 52.74$ (C-6), 22.41 (C-7, C-8); MS (ESI): $\mathrm{m} / \mathrm{z}$ $196.1\left(\mathrm{M}+\mathrm{H}^{+}, 100 \%\right)$; HRMS: calcd for $\mathrm{C}_{8} \mathrm{H}_{14} \mathrm{~N}_{5} \mathrm{O}[\mathrm{M}+\mathrm{H}]^{+}$196.11984, found 196.11963.

2,4-Diamino-6-choloromethyl-5,6,7,8-tetrahydropyrido[3,2-d]pyrimidine (7): A stirred solution of compound $6(502 \mathrm{mg}, 5.1 \mathrm{mmol})$ in $\mathrm{POCl}_{3}(10 \mathrm{~mL})$ was refluxed at $110{ }^{\circ} \mathrm{C}$ for $2 \mathrm{~h}$. The resulting solution was evaporated to a minimized volume of about $1 \mathrm{~mL}$ under reduced pressure. Then it was diluted with $50 \mathrm{~mL}$ dichloromethane and evaporated to a minimized volume again. This procedure was repeated twice with diluting solvent changing successively to ethanol and methanol. Acetone $(50 \mathrm{~mL})$ was added to the concentrated sticky liquid, and the resulting white precipitate was filtered, washed with acetone $(20 \mathrm{~mL})$ and dried under vacuum to afford $221 \mathrm{mg}(40.2 \%$ yield) of 7 as an off-white solid; m.p. $228 \sim 232{ }^{\circ} \mathrm{C} .{ }^{1} \mathrm{H}-\mathrm{NMR}\left(400 \mathrm{MHz}, \mathrm{DMSO}-d_{6}\right): \delta=4.06 \sim 3.92\left(\mathrm{~m}, 2 \mathrm{H}, \mathrm{CH}_{2} \mathrm{Cl}\right), 3.70 \sim 3.68$ 
(m, 1H, 6-CH), 2.64 2.44 (m, 2H, 8- $\left.\mathrm{CH}_{2}\right), 1.98 \sim 1.95\left(\mathrm{~m}, 1 \mathrm{H}, 7-\mathrm{CH}_{\mathrm{a}} \mathrm{H}_{\mathrm{b}}\right), 1.77 \sim 1.70\left(\mathrm{~m}, 1 \mathrm{H}, 7-\mathrm{CH}_{\mathrm{a}} H_{\mathrm{b}}\right)$; ${ }^{13} \mathrm{C}-\mathrm{NMR}\left(100 \mathrm{MHz}, \mathrm{DMSO}-d_{6}\right): \delta=51.79(6-\mathrm{CH}), 47.35(\mathrm{CH} \mathrm{Cl}), 23.19\left(7-\mathrm{CH}_{2}\right), 22.04\left(8-\mathrm{CH}_{2}\right)$; MS (ESI): $m / z 214.1\left(\mathrm{M}+\mathrm{H}^{+}\right.$, isotopic peak of $\left.{ }^{37} \mathbf{C l}, 100 \%\right), 216.1\left(\mathrm{M}+\mathrm{H}^{+}\right.$, isotopic peak of ${ }^{35} \mathbf{C l}$, 33.6\%); HRMS: calcd for $\mathrm{C}_{8} \mathrm{H}_{13} \mathrm{ClN}_{5}[\mathrm{M}+\mathrm{H}]^{+} 214.08595$, found 214.08617 .

\section{2,4-Diamino-5,6-methylene-5,6,7,8-tetrahydropyrido[3,2-d]pyrimidine (5)}

Method A: To a suspension of compound $7(296 \mathrm{mg}, 1.4 \mathrm{mmol})$ in acetonitrile $(25 \mathrm{~mL})$ was added 1,8-diazabicyclo[5.4.0]undec-7-ene (DBU, $0.60 \mathrm{~mL}, 4.1 \mathrm{mmol}$ ). The reaction was stirred at room temperature for $1 \mathrm{~h}$, then concentrated and isolated by preparative TLC with a chloromethane and methanol mixture (9:1) as eluent. Compound $5(210 \mathrm{mg})$ was obtained as a faint yellow solid, the yield was $85.7 \%$, while the two-step overall yield from compound 6 was $34.5 \%$.

Method B: To a suspension of compound $6(300 \mathrm{mg}, 1.5 \mathrm{mmol})$ in anhydrous THF $(10 \mathrm{~mL})$ was added $50 \%$ aq. sodium hydroxide solution $(4.0 \mathrm{~mL}, 76.3 \mathrm{mmol})$ and tetrabutylammonium iodide $(101 \mathrm{mg}$, $0.3 \mathrm{mmol}) \cdot p$-Toluenesulfonyl chloride $(291 \mathrm{mg}, 1.5 \mathrm{mmol}$ ) was added after stirring for $10 \mathrm{~min}$. The reaction mixture was stirred at room temperature for $1 \mathrm{~h}$, and diluted with ethyl acetate $(100 \mathrm{~mL})$ and stirred thoroughly. The resulting solution was then filtered through kieselguhr and washed with dichloromethane $(50 \mathrm{~mL})$. The filtrate and washes were combined, concentrated and subjected to preparative TLC with a dichloromethane and methanol mixture (9:1) as eluent. Compound 5 (137 mg, $50.3 \%$ ) was obtained as a faint yellow solid; m.p. $223 \sim 226{ }^{\circ} \mathrm{C} .{ }^{1} \mathrm{H}-\mathrm{NMR}$ (400 MHz, DMSO- $d_{6}$ ): $\delta=6.12\left(\mathrm{~s}, 2 \mathrm{H}, 4-\mathrm{NH}_{2}\right), 5.52\left(\mathrm{~s}, 2 \mathrm{H}, 2-\mathrm{NH}_{2}\right), 2.48 \sim 2.47(\mathrm{~m}, 1 \mathrm{H}, 6-\mathrm{CH}), 2.34 \sim 2.28\left(\mathrm{~m}, 1 \mathrm{H}, 8-\mathrm{CH}_{\mathrm{a}} \mathrm{H}_{\mathrm{b}}\right)$, 2.27 2.19 (m, 1H, 8- $\left.\mathrm{CH}_{\mathrm{a}} H_{\mathrm{b}}\right), 2.14 \sim 2.13\left(\mathrm{~d}, J=5.2 \mathrm{~Hz}, 1 \mathrm{H}, \mathrm{NCH}_{\mathrm{a}} \mathrm{H}_{\mathrm{b}}\right), 2.09 \sim 2.06\left(\mathrm{~m}, 1 \mathrm{H}, 7-\mathrm{CH}_{\mathrm{a}} \mathrm{H}_{\mathrm{b}}\right)$, $1.96 \sim 1.91\left(\mathrm{~m}, 1 \mathrm{H}, 7-\mathrm{CH}_{\mathrm{a}} H_{\mathrm{b}}\right), 1.56 \sim 1.55\left(\mathrm{~d}, J=4.0 \mathrm{~Hz}, 1 \mathrm{H}, \mathrm{NCH}_{\mathrm{a}} H_{\mathrm{b}}\right) ;{ }^{13} \mathrm{C}-\mathrm{NMR}\left(100 \mathrm{MHz}, \mathrm{DMSO}-d_{6}\right)$ : $\delta=160.50$ (2-C), 159.09 (4-C), 154.62 (8a-C), 117.48 (4a-C), $35.23(6-\mathrm{CH}), 33.33\left(\mathrm{~N}^{-} \mathrm{CH}_{2}\right), 25.26$ $\left(8-\mathrm{CH}_{2}\right), 21.05\left(7-\mathrm{CH}_{2}\right)$; MS (ESI): $m / z 178.1\left(\mathrm{M}+\mathrm{H}^{+}, 100 \%\right)$; HRMS (ESI): calcd for $\mathrm{C}_{8} \mathrm{H}_{12} \mathrm{~N}_{5}$ $[\mathrm{M}+\mathrm{H}]^{+} 178.10872$, found 178.10813 .

Diethyl $\quad N-\{4-[(2,4-$ diamino-5,6,7,8-tetrahydropyrido[3,2-d]pyrimidin-6-yl)methylamino]benzoyl $\}$-Lglutamate (1): Silica gel was activated at $120{ }^{\circ} \mathrm{C}$ under vacuum for $6 \mathrm{~h}$ before use. Compound 5 $(139 \mathrm{mg}, 0.8 \mathrm{mmol})$ and diethyl 4-aminobenzoyl-L-glutamate $(310 \mathrm{mg}, 1.0 \mathrm{mmol})$ were mixed uniformly with activated silica gel $(1.02 \mathrm{~g})$. The mixture was stirred vigorously for $24 \mathrm{~h}$, and stopped when TLC showed full transformation of 5. The reactant was purified by column chromatography (silica gel). Elution with $\mathrm{CHCl}_{3}-\mathrm{CH}_{3} \mathrm{OH}(12: 1)$ gave pure 1 (356 mg, 90.8\%) as a white solid; m.p. $143{ }^{\circ} \mathrm{C}$ (decomp). ${ }^{1} \mathrm{H}-\mathrm{NMR}\left(400 \mathrm{MHz}, \mathrm{DMSO}-d_{6}\right): \delta=8.27 \sim 8.25$ (d, $\left.J=7.3 \mathrm{~Hz}, 1 \mathrm{H}, \mathrm{CONH}\right)$, 7.69 7.67 (d, $J=8.7 \mathrm{~Hz}, 2 \mathrm{H}, 2,6-\mathrm{H}$ on benzene ring), 7.29 (s, $\left.2 \mathrm{H}, 4-\mathrm{NH}_{2}\right), 6.67 \sim 6.64(\mathrm{~d}, J=8.7 \mathrm{~Hz}$, $2 \mathrm{H}, 3,5-\mathrm{H}$ on benzene ring), $6.55 \sim 6.53(\mathrm{~d}, J=8.5 \mathrm{~Hz}, 1 \mathrm{H}, 5-\mathrm{NH}), 6.50 \sim 6.47(\mathrm{t}, J=5.7 \mathrm{~Hz}, 1 \mathrm{H}$, $\left.\mathrm{CH}_{2} \mathrm{NH}\right), 4.40 \sim 4.35(\mathrm{~m}, 1 \mathrm{H}, \mathrm{CONHCH}), 4.11 \sim 4.02\left(\mathrm{~m}, 4 \mathrm{H}, \mathrm{CH}_{2} \mathrm{CH}_{3} \times 2\right), 3.68 \sim 3.65(\mathrm{~m}, 1 \mathrm{H}, 6-\mathrm{CH})$, $3.21 \sim 3.17\left(\mathrm{~m}, 2 \mathrm{H}, \mathrm{CH}_{2} \mathrm{NH}\right), 2.43 \sim 2.39\left(\mathrm{~m}, 4 \mathrm{H}, 8-\mathrm{CH}_{2}, \mathrm{CHCH}_{2} \mathrm{CH}_{2}\right), 2.12 \sim 1.97$ (m, 4H, 7-CH ${ }_{2}$, $\mathrm{CHCH}_{2} \mathrm{CH}_{2}$ ), $1.18 \sim 1.16\left(\mathrm{~m}, 6 \mathrm{H}, \mathrm{CH}_{3} \times 2\right)$; MS (ESI): $m / z 499.3\left(\mathrm{M}+\mathrm{H}^{+}, 100 \%\right)$; HRMS (ESI): calcd for $\mathrm{C}_{24} \mathrm{H}_{34} \mathrm{~N}_{7} \mathrm{O}_{5}[\mathrm{M}+\mathrm{H}]^{+} 500.26159$, found 500.26051 .

Diethyl $\quad N-\{4-[(2,4-d i a m i n o-5,6,7,8-t e t r a h y d r o p y r i d o[3,2-d]$ pyrimidin-6-yl)methylamino] thiophene-2formyl $\}$-L-glutamate (10): The heterocyclic benzoyl analogue $\mathbf{1 0}$ was prepared in the similar way as the 
synthesis of $\mathbf{1}$. Compound 5 (144 mg, $0.8 \mathrm{mmol})$, diethyl $N$-(4-aminothiophene-2-formyl)-L-glutamate (600 $\mathrm{mg}, 1.8 \mathrm{mmol})$ and activated silica gel $(1.6 \mathrm{~g})$ was stirred together for $48 \mathrm{~h}$ to complete the reaction. Product was purified by column chromatography (silica gel). Elution with $\mathrm{CHCl}_{3}-\mathrm{CH}_{3} \mathrm{OH}$ (15:1) gave pure $10(186 \mathrm{mg}, 45.3 \%)$ as a faint yellow liquid. ${ }^{1} \mathrm{H}-\mathrm{NMR}\left(400 \mathrm{MHz}, \mathrm{CDCl}_{3}\right): \delta=7.16$ (s, 1H, 2-H on thiophene ring), 6.10 (s, 1H, 4-H on thiophene ring), 5.21 (br.s, 1H, 5-NH), 4.72 (br.s, $1 \mathrm{H}, \mathrm{CH}_{2} \mathrm{NH}$ ), 4.58 (br.s, 1H, $\mathrm{CONHCH}$ ), 4.18 (m, 2H, $\left.\mathrm{CHCOOCH}_{2}\right), 4.10 \sim 4.09$ (m, 3H, $\left.\mathrm{CH}_{2} \mathrm{COOCH}_{2}, 6-\mathrm{CH}\right), 3.31\left(\mathrm{~m}, 1 \mathrm{H}, \mathrm{CH}_{\mathrm{a}} \mathrm{H}_{\mathrm{b}} \mathrm{NH}\right), 3.14\left(\mathrm{~m}, 1 \mathrm{H}, \mathrm{CH}_{\mathrm{a}} H_{\mathrm{b}} \mathrm{NH}\right), 2.64 \sim 2.35\left(\mathrm{~m}, 4 \mathrm{H}, 8-\mathrm{CH}_{2}\right.$, $\mathrm{CHCH}_{2} \mathrm{CH}_{2}$ ), 2.27 2.10 (m, 4H, 7- $\mathrm{CH}_{2}, \mathrm{CHCH}_{2} \mathrm{CH}_{2}$ ), 1.24 1.22 (m, 6H, $\left.\mathrm{CH}_{3} \times 2\right)$; HRMS (ESI): calcd for $\mathrm{C}_{22} \mathrm{H}_{32} \mathrm{~N}_{7} \mathrm{O}_{5} \mathrm{~S}[\mathrm{M}+\mathrm{H}]^{+}$506.21801, found 506.21906.

Diethyl $\quad N-\{5-[(2,4-d i a m i n o-5,6,7,8-t e t r a h y d r o p y r i d o[3,2-d]$ pyrimidin-6-yl)methylamino]thiophene-2formyl\}-L-glutamate (11): The heterocyclic benzoyl analogue 11 was prepared in the same way as the synthesis of 10. Compound 5 (96 mg, $0.5 \mathrm{mmol}), N$-(5-aminothiophene-2-formyl)-L-glutamate (403 mg, $1.2 \mathrm{mmol})$ and activated silica gel $(1.05 \mathrm{~g})$ was stirred together for $48 \mathrm{~h}$ to complete the reaction. Product was purified by column chromatography (silica gel). Elution with $\mathrm{CHCl}_{3}-\mathrm{CH}_{3} \mathrm{OH}$ (15:1) gave pure $11(120 \mathrm{mg}, 43.8 \%)$ as a faint yellow liquid. ${ }^{1} \mathrm{H}-\mathrm{NMR}\left(400 \mathrm{MHz}, \mathrm{CDCl}_{3}\right): \delta=7.26(\mathrm{~s}, 1 \mathrm{H}, 2-\mathrm{H}$ on thiophene ring, coincided with $\mathrm{CHCl}_{3}$ peak), $6.42(\mathrm{~s}, 1 \mathrm{H}, 3-\mathrm{H}$ on thiophene ring), $5.30(\mathrm{~s}, 1 \mathrm{H}, 5-\mathrm{NH}$, coincided with residual $\mathrm{CH}_{2} \mathrm{Cl}_{2}$ peak), $4.63\left(\mathrm{~m}, 2 \mathrm{H}, \mathrm{CH}_{2} \mathrm{NH}, \mathrm{CONHCH}\right), 4.18 \sim 4.17(\mathrm{~m}, 2 \mathrm{H}$, $\left.\mathrm{CHCOOCH}_{2}\right), 4.09 \sim 4.08\left(\mathrm{~m}, 2 \mathrm{H}, \mathrm{CH}_{2} \mathrm{COOCH}_{2}\right), 3.60(\mathrm{~m}, 1 \mathrm{H}, 6-\mathrm{CH}), 3.41 \sim 3.35\left(\mathrm{~m}, 2 \mathrm{H}, \mathrm{CH}_{2} \mathrm{NH}\right)$, 2.65 2.64 (m, 1H, 8- $\left.\mathrm{CH}_{\mathrm{a}} \mathrm{H}_{\mathrm{b}}\right), 2.43\left(\mathrm{~m}, 2 \mathrm{H}, \mathrm{CHCH}_{2} \mathrm{CH}_{2}\right), 2.27 \sim 2.26\left(\mathrm{~m}, 1 \mathrm{H}, 8-\mathrm{CH}_{\mathrm{a}} H_{\mathrm{b}}\right), 2.22 \sim 2.17(\mathrm{~m}$, $\left.1 \mathrm{H}, \mathrm{CHCH}_{\mathrm{a}} \mathrm{H}_{\mathrm{b}} \mathrm{CH}_{2}\right), 2.08\left(\mathrm{~m}, 2 \mathrm{H}, \mathrm{CHCH}_{\mathrm{a}} \mathrm{H}_{\mathrm{b}} \mathrm{CH}_{2}, 7-\mathrm{CH}_{\mathrm{a}} \mathrm{H}_{\mathrm{b}}\right), 1.91\left(\mathrm{~m}, 1 \mathrm{H}, 7-\mathrm{CH}_{\mathrm{a}} H_{\mathrm{b}}\right), 1.22 \sim 1.19$ (m, $6 \mathrm{H}, \mathrm{CH}_{3} \times 2$ ); HRMS (ESI): calcd for $\mathrm{C}_{22} \mathrm{H}_{32} \mathrm{~N}_{7} \mathrm{O}_{5} \mathrm{~S}[\mathrm{M}+\mathrm{H}]^{+}$506.21801, found 506.21947.

\section{Methyl 5-[(2,4-diamino-5,6,7,8-tetrahydropyrido[3,2-d]pyrimidin-6-yl)methylamino]furan-2-carboxylate} (12): The heterocyclic benzoyl analogue 11 was prepared in a similar way as in the synthesis of 1 . Compound 5 (90 mg, $0.5 \mathrm{mmol}$ ), methyl 5-aminofuran-2-formate (181 mg, $1.3 \mathrm{mmol}$ ) and activated silica gel $(501 \mathrm{mg})$ was stirred together for $36 \mathrm{~h}$ to complete the reaction. Product was purified by column chromatography (silica gel). Elution with $\mathrm{CHCl}_{3}-\mathrm{CH}_{3} \mathrm{OH}$ (15:1) gave pure 12 (104.5 mg, $40.7 \%$ ) as a faint yellow liquid. HRMS (ESI): calcd for $\mathrm{C}_{14} \mathrm{H}_{19} \mathrm{~N}_{6} \mathrm{O}_{3}[\mathrm{M}+\mathrm{H}]^{+} 319.15186$, found 319.15244 .

\section{Conclusions}

In conclusion, we have developed a novel synthetic route providing the biologically important compound 1 in good yields via an aziridine intermediate, thus avoiding the benzylic hydrogenolysis of the carbon-nitrogen bond of earlier methods. It also represents a convenient preparation of tetrahydroaminopterin or tetrahydrofolate analogues.

\section{Acknowledgments}

This study was supported by the National Science Foundation of China (20972011, 21042009, 21172014) and grants from the Ministry of Science and Technology of China (2009ZX09301-010) for financial support. 


\section{References and Notes}

1. Christopherson, R.I.; Lyons, S.D. Potent inhibitors of de novo pyrimidine and purine biosynthesis as chemotherapeutic agents. Med. Res. Rev. 1990, 10, 505-548.

2. Appling, D.R. Compartmentation of folate-mediated one-carbon metabolism in eukaryotes. FASEB J. 1991, 9, 482-487.

3. Daidone, F.; Florio, R.; Rinaldo, S.; Contestabile, R.; di Salvo, M.L.; Cutruzzola, F.; Bossa, F.; Paiardini, A. In silico and in vitro validation of serine hydroxymethyltransferase as a chemotherapeutic target of the antifolate drug pemetrexed. Eur. J. Med. Chem. 2011, 46, 1616-1621.

4. Berger, S.H.; Pittman, D.L.; Wyatt, M.D. Uracil in DNA: Consequences for arcinogenesis and chemotherapy. Biochem. Pharmacol. 2008, 76, 697-706.

5. Goodman, L.; Kisliuk, R.L.; Pastore, E.J.; Plante, L.T.; Al-Nahas, A.; Morningstar, J.F.; Kwok, G.; Wilson, L.; Donovan, E.F.; Ratzan, J. Tetrahydrohomofolate, a specific inhibitor of thymidylate synthetase. J. Am. Chem. Soc. 1964, 86, 308-309.

6. Taylor, E.C.; Harrington, P.J.; Fletcher, S.R.; Beardsley, G.P.; Moran, R.G. Synthesis of the antileukemic agents 5,10-dideazaaminopterin and 5,10-dideaza-5,6,7,8-tetrahydroaminopterin. J. Med. Chem. 1985, 28, 914-921.

7. Boritzki, T.J.; Barlett, C.A.; Zhang, C.; Howland, E.F.; Margosiak, S.A.; Palmer, C.L.; Romines, W.H.; Jackson, R.C. AG2034: A novel inhibitor of glycinamide ribonucleotide formyltransferase. Invest. New Drugs 1996, 14, 295-303.

8. Barnett, C.J.; Wilson, T.M.; Evans, D.A.; Somers, T.C. Asymmetric synthesis of dideazafolate antitumor agents via amidomethylation of nonracemic oxazolidinone imidates. Synthesis of LY309887, a cytotoxic dideazafolate analog related to lometrexol. Tetrahedron Lett. 1997, 38, $735-738$.

9. Rosowsky, A.; Forsch, R.A.; Reich, V.E.; Freisheim, J.H.; Moran, R.G. First use of the Taylor pteridine synthesis as a route to polyglutamate derivatives of antifolates. 46. Side chain modified 5-deazafolate and 5-deazatetrahydrofolate analogs as mammalian folylpolyglutamate synthetase and glycinamide ribonucleotide formyl transferase inhibitors: Synthesis and in vitro biological evaluation. J. Med. Chem. 1992, 35, 1578-1588.

10. Tang, C.; Zhang, Z.L.; Xu, B.; Li, M.; Liu, J.Y.; Cui, J.R. Two newly synthesized 5-methyltetrahydrofolate-like compounds inhibit methionine synthase activity accompanied by cell cycle arrest in G1/S phase and apoptosis in vitro. Anti-Cancer Drugs 2008, 19, 697-704.

11. Zhang, Z.L.; Wu, J.; Ran, F.X.; Guo, Y.; Tian, R.; Zhou, S.X.; Wang, X.W.; Liu, Z.M.; Zhang, L.R.; Cui, J.R.; et al. Novel 8-deaza-5,6,7,8-tetrahydroaminopterin derivatives as dihydrofolate inhibitor: Design, synthesis and antifolate activity. Eur. J. Med. Chem. 2009, 44, 764-771.

12. Temple, C., Jr.; Kussner, C.L.; Rose, J.D.; Smithers, D.L.; Bennett, L.L., Jr.; Montgomery, J.A. New synthesis of $N$-[4-[[(2-amino-4(3H)-oxopyrido[3,2- $d]$ pyrimidin-6-yl)methyl]amino]benzoyl]$L$-glutamic acid (8-deazafolic acid) and the preparation of some 5,6,7,8-tetrahydro derivatives. J. Med. Chem. 1981, 24, 1254-1258.

13. Gangjee, A.; Shi, J.; Queener, S.F.; Barrows, L.R.; Kisliuk, R.L. Synthesis of 5-methyl-5-deaza nonclassical antifolates as inhibitors of dihydrofolate reductases and as potential antipneumocystis, antitoxoplasma, and antitumor agents. J. Med. Chem. 1993, 36, 3437-3443. 
14. Taylor, E.C.; Hamby J.M.; Shih, C.; Grindey, G.B.; Rinzel, S.M.; Beardsley, G.P.; Moran, R.G. Synthesis and antitumor activity of 5-deaza-5,6,7,8-tetrahydrofolic acid and its N10-substituted analogs. J. Med. Chem. 1989, 32, 1517-1522.

15. Singh, S.K.; Singer, S.C.; Ferone, R.; Waters, K.A.; Mullin, R.J.; Hynes, J.B. Synthesis and biological evaluation of N.alpha.-(5-deaza-5,6,7,8-tetrahydropteroyl)-L-ornithine. J. Med. Chem. 1992, 35, 2002-2006.

16. Pomel, V.; Gaillard, P.; Desforges, G.; Quattropani, A.; Montagne, C. 4-Morpholino-pyrido[3,2d]pyrimidines. WO 2010037765, 2010.

17. Srinivasan, A.; Broom, A.D. Pyridopyrimidines. 12. Synthesis of 8-deaza analogs of aminopterin and folic acid. J. Org. Chem. 1981, 46, 1777-1781.

18. Anand, R.V.; Pandey, G.; Singh, V.K. Silica gel induced cleavage of aziridines by aromatic amines under solvent free conditions. Tetrahedron Lett. 2002, 43, 3975-3976.

19. Sweeney, J.B. Aziridines: Epoxides' ugly cousins? Chem. Soc. Rev. 2002, 31, 247-258.

20. Hu, X.E. Nucleophilic ring opening of aziridines. Tetrahedron 2004, 60, 2701-2743.

21. Watson, I.D.G.; Yu, L.; Yudin, A.K. Advances in nitrogen transfer reactions involving aziridines. Acc. Chem. Res. 2006, 39, 194-206.

22. Eis, M.J.; Ganem, B. $\mathrm{BF}_{3}$-etherate promoted alkylation of aziridines with organocopper reagents: A new synthesis of amines. Tetrahedron Lett. 1985, 26, 1153-1156.

23. Nishikawa, T.; Ishikawa, M.; Wade K.; Isobe, M. Total synthesis of $\alpha$-C-mannosyltryptophan, a naturally occurring C-glycosyl amino acid. Synlett 2001, 10, 945-947.

24. Yavad, J.S.; Reddy, B.V.S.; Rao, K.V.; Raj, K.S.; Prasad, A.R. Indium tribromide catalyzed aminolysis of aziridines: An efficient synthesis of vicinal-diamines. Synthesis 2002, 13, 1061-1064.

25. Watson, I.D.G.; Yudin, A.K. Ring-opening reactions of nonactivated aziridines catalyzed by tris(pentafluorophenyl)borane. J. Org. Chem. 2003, 68, 5160-5167.

26. Kotake, Y.; Okauchi, T.; Iijima, A.; Yoshimatsu, K.; Nomura, H. Novel 6-5 fused ring heterocycle antifolates with potent antitumor activity: Bridge modifications and heterocyclic benzoyl isosters of 2,4-diamino-6,7-dihydro-5H-cyclopenta[d]pyrimidine Antifolate. Chem. Pharm. Bull. 1995, 43, 829-841.

27. Jackman, A.L.; Marsham, P.R.; Moran, R.G.; O’Connor, B.M.; Hughes, L.R.; Calverts, A.H. Thymidylate synthase inhibitors: The in vitro activity of a series of heterocyclic benzoyl ring modified 2-desamino-2-methyl-N ${ }^{10}$-substituted-5,8-dideazafolates. Adv. Enzyme Regul. 1991, 31, 13-27.

28. Jackman, A.L.; Calvert, A.H. Folate-based thymidylate synthase inhibitors as anticancer drugs. Ann. Oncol. 1995, 6, 871-881.

29. Hodson, S.J.; Bigham, E.C.; Duch, S.D.; Smith, G.K.; Ferone, R. Thienyl and thiazolyl acyclic analogues of 5-deazatetrahydrofolic acid. J. Med. Chem. 1994, 37, 2112-2115.

Sample Availability: Not available.

(C) 2012 by the authors; licensee MDPI, Basel, Switzerland. This article is an open access article distributed under the terms and conditions of the Creative Commons Attribution license (http://creativecommons.org/licenses/by/3.0/). 